International Journal of Fuzzy Logic Systems (IJFLS) Vol.6, No.2, April 2016

\title{
OPTIMAL ALTERNATIVE SELECTION USING MOORA IN INDUSTRIAL SECTOR - A REVIEW
}

\author{
Karuppanna Prasad $\mathrm{N}^{1}$ and Sekar $\mathrm{K}^{2}$ \\ ${ }^{1}$ Technical Training Centre, TVS Training and Services Ltd, Chennai, India \\ and \\ ${ }^{2}$ Department of Mechanical Engineering, National Institute of Technology, Calicut, India
}

\begin{abstract}
Modern manufacturing organizations tend to face versatile challenges due to globalization, modern lifestyle trends and rapid market requirements from both locally and globally placed competitors. The organizations faces high stress from dual perspective namely enhancement in science and technology and development of modern strategies. In such an instance, organizations were in a need of using an effective decision making tool that chooses out optimal alternative that reduces time, complexity and highly simplified. This paper explores a usage of new multi criteria decision making tool known as MOORA for selecting the best alternatives by examining various case study. The study was covered up in two fold manner by comparing MOORA with other MCDM and MADM approaches to identify its advantage for selecting optimal alternative, followed by extending MOORA with interval grey numbers, crisp and interval grey number and whitening coefficient and future scope of the present work concentrate on highlighting the scope and gap between MOORA, Multiplicative form of MOORA(MULTIMOORA) and Multi objective optimization on the basis of simple ratio analysis (MOOSRA) for numerous manufacturing and service applications.
\end{abstract}

\section{KEYWORDS:}

MADM, MCDM, MOORA, optimization, manufacturing sector, service sector

\section{INTRODUCTION}

In modern trend, manufacturing organizations tend to face versatile challenges due to globalization, modern lifestyle trends and rapid market requirements from both locally and globally placed competitors [30] [34]. Modern organizations were in a need to improve their overall performance in market and build up a competitive advantage [32]. To improve the overall performance, organization had to deliver enhanced quality products for pacifying the customers [17]. The delivery of embarked quality products was commonly differentiated into three index values such as customer expected level, satisfaction level and achieved level of quality [12]. The improvement in satisfaction level of quality was declined, since many conventional manufacturing units faces high stress from dual perspectives namely enhancement in science and DOI : $10.5121 /$ ijfls.2016.6201 
technology that consequence towards developing of modern strategies and versatile customer requirements [36] [24]. There exist numerous theories, models and approaches that reveal the change in a paradigm shift from craft manufacturing towards mass manufacturing, lean manufacturing and agile manufacturing [36] [35] that reduces the stress from conventional manufacturing units. The change up in a paradigm shift internally had made managers in conventional units to reconsider their decision making ability for selecting the best production system [24]. The concept selection through decision making was an imperative approach that nurtures creative and innovative ideas by thriving towards choosing of optimal alternative [33], based on values, beliefs and perceptions [7] [11]. Decision makers in manufacturing and service sector select an optimal alternative with a set of conflicting objectives through dynamic mind set [15]. All the aforementioned statements reveals, manufacturing and service organization faces a stressful task on decision making due to dynamic decision makers ability for choosing the best alternative.

In present days, organizations were in a need of using an effective decision making tool that gives out optimized results from discrete inputs within a shorter period of time with effective decision making ability. Decision making involve human being vagueness, inconsistency and incompleteness that making decision making an onerous task [43] [42]. The ameliorating emphasize on decision making purely depends on decision makers mantling of onerous circumstances in versatile competitive environment [23] to choose the optimal alternative with conflicting criteria's. Optimal selection of alternatives based on set of conflicting criteria's involves optimization a tool that deals with a kind of problem which either maximizes or minimizes the single or multi objectives was a numerical functions of real or integer variables [3]. The optimization in general was broadly classified into single objective optimization (SOO) and multi objective optimization (MOO) problem. The main goal of SOO was to find the best value of objective function for making up an optimal solution by satisfying set of feasible solution [3]. The SOO selects the best alternative by using approaches such as calculus based techniques, enumerative and random techniques involving genetic algorithm (GA) and simulation annealing (SA) [3]. The numerical methods or calculus based methods uses necessary and sufficient conditions for satisfying solution in optimization problem. Numerical methods were further classified into direct and indirect search methods for selecting optimal solution. Enumerative techniques involve each and every point of finite and infinite search space to attain an optimal solution [3]. In many real life problem, we face a circumstance were improvement in one objective leads to impact on another objective basically known as MOO that perform parallel optimizing of two or more conflicting objectives that leads to automation, semi automation in industrial applications [3] [17]. The MOO were applicable in numerous applications such as product and process design, network analysis, finance, aircraft design [3] [17]. The usage of MOO in above said fields along with maintenance optimization was to choose the best responses through nature of information that can be either qualitative or quantitative [1]. The qualitative measurements of input information to quantitative assessment of output falls upon using multicriteria decision making (MCDM) method like analytical hierarchy process (AHP), game theory and fuzzy sets that are used for identifying the imperative criteria's and alternatives [26] [7].There exists approaches like elimination and choice translation reality (ELECTRE), preference ranking organization method for enrichment and evaluation (PROMTHEE) that uses quantitative assessment of data by comparing little criteria. The method like decision making trial and evaluation laboratory (DEMATEL) evaluates and creates the casual relationship within the 
criteria's [29]. There are also approaches like verbal decision analysis (VDA) that deals with qualitative data assessment to provide qualitative results [7]. In literature's their avail usage of other approaches for solving MOO problem they are such as aggregating, population based pareto and non pareto approach, vector evaluated genetic algorithm (VEGA), multi objective GA (MOGA), non-dominated GA (MSGA) and niched pareto GA (PGA) [3].

During the second part of twenty century, MCDM method proves to be an emerging area in operational research for identifying the optimal options that impacts multiple of conflicting criteria's [31].The MCDM ameliorate on effective decision making to choose an optimal solution from the available feasible alternative that involves impact of multiple often conflicting criteria [40]. The MCDM method was broadly classified into multi attribute decision making (MADM) and multi objective decision making (MODM) approach as shown in figure 1 [31] [43].

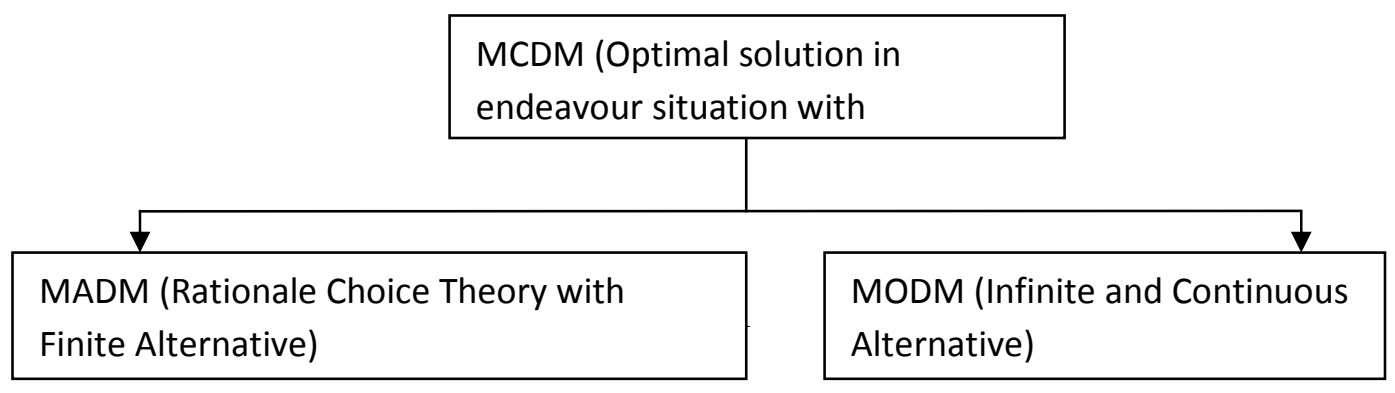

Figure-1: Hierarchical classification of MCDM approach

The MADM approach was the ranking of best alternative with most attractive attributes [8]. Unlike MADM approaches, MODM method designs the best alternative with multiple objectives that depends on continuous decision variables subject to certain constraints [9]. The endemically used MADM approaches for identifying the optimal solutions with discrete alternatives were namely taguchi method, desirability function, response surface methodology (RSM), inner/outer orthogonal array (I/O OA), technique for order preference by similarity to ideal solution(TOPSIS), VIseKriterijumska Optimizacijai kompromisno Resenje in Serbian (VIKOR), complex proportional assessment(COPRAS), grey relational analysis(GRA),multi objective optimization on the basis of ratio analysis (MOORA) that converts MOO problem into SOO [17]. This paper exposes a use of quantitative assessment method namely MOORA that proves to be a foreseen MADM approach over other approaches with high stability, robustness and less computational time for selecting optimal alternative by satisfying set of conflicting criteria. The study on MOORA is explored in two fold manner, initially the MOORA have been compared with aforesaid MCDM and MADM approaches to identify its usability and advantage for selecting optimal alternative. On other side, paper highlights scope and gap of using MOORA approach through intensify examining of case studies in manufacturing and service sector that propel the empirical benefits of MOORA.

The hierarchical nomenclature of the study starts with methodology in part-2,literature review on usage of MOORA in manufacturing and servicing sector in part-3,gap assessment in part-4 and conclusion in part-5. 


\section{METHODOLOGY}

An endemic theory and pragmatic evaluation on optimization, SOO and MOO approaches were said to be available in different web of knowledge portals and conference proceedings. There avail accessibility of articles related on applicability of optimization, SOO and MOO in manufacturing and service sector on leading elite citation databases namely Taylor and Francis (www.tandfonline.com), Science direct (www.sciencedirect.com), Springer link (www.springerlink.com), control and cybernetics (http://control.ibspan.waw.pl:3000/mainpage),journal of military and information sciences (www.jmisci.com), engineering economics (www.inzeko.ktu.lt/index.php/EE).In the initial stages of surveying articles, the searching starts with journals titled on optimization, SOO and MOO in manufacturing and service sector from year 2000 to present in aforementioned web of knowledge portals. There exist myriad of articles to limit the search by making a shift from optimization, SOO and MOO towards empirical usage of MOORA that reduces the list to 43.In final list of 43 articles the 25 articles uses the MOORA concept by differentiating 11 cases on manufacturing sector and remaining 14 on service sector as shown in Figure 2.

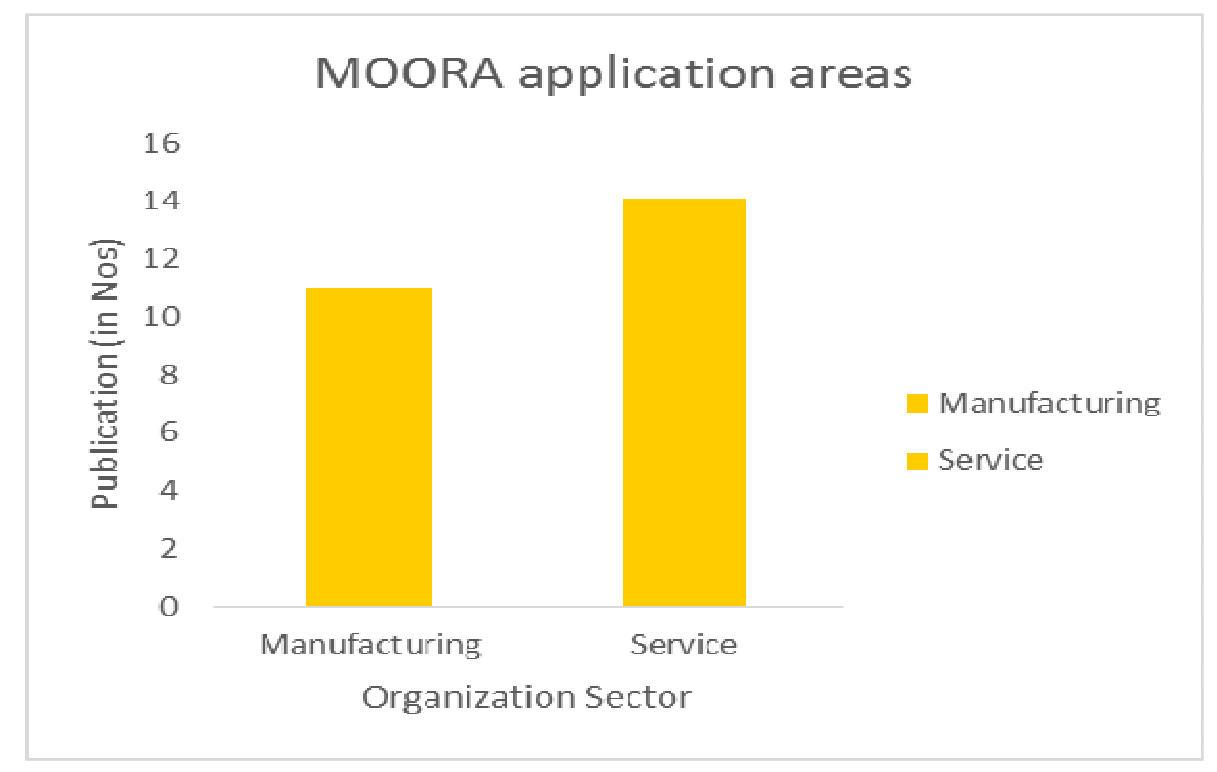

Figure-2. Papers on MOORA in manufacturing and service sector

Finalized list of articles are thoroughly overviewed to identify the intensify realization on using MOORA for achieving good manufacturing growth, profit with high stability, robustness and less computational time for selecting optimal alternative with set of conflicting criteria in discrete cases. 
International Journal of Fuzzy Logic Systems (IJFLS) Vol.6, No.2, April 2016

\section{MULTI OBJECTIVE OPTIMIZATION ON THE BASIS OF RATIO ANALYSIS (MOORA)}

In real time, making up of optimal decision to satisfy the customer proven to be a focal part in manufacturing sector [11]. MOORA a MADM approach was used to attain the best solution among given discrete alternatives with conflicting objectives [17]. In early stages multiplicative form of generating dimensionless numbers were elaborated by Scharling (1985) and Brauers (1997, 1999, 2002 and 2004) with later stages there evolve a usage of ratio analysis approach with respective to dimensionless measure known as MOORA [8]. MOORA a cardinal approach isolates extreme and non-convex points by providing insight to mid-way solution as per economical law of decreasing marginal utility [10]. MOORA was first introduced by Brauers and Zavadaskas in the year 2006[8] [10] [19]. MOORA was proven to be a robustic approach over minkowski, Euclidean distance metric, tchebycheff min max metric [10]. In MOORA, performing of Multi response optimization or MOO was done by satisfying constraints and feasible solution. The MOORA was viewed as a ratio and reference point system [2].

MOORA as an approach satisfies the seven conditions to be looked foreseen over other MADM or MODM techniques [8] [11]. MOORA proves to be a best MADM approach for attaining optimal decisions within less computational time and no usage of extra parameters like $v$ in VIKOR and $\xi$ in GRA method [11] [2]. The MOORA have merits over other MADM approaches as compared and revealed in Table 1. The comparisons illustrate, MOORA chooses best alternative with high simpleness, less computational time and with basic mathematical calculations [2]. The second phase of this review article will elaborately corroborate on empirical benefits of using MOORA with other MADM methods through various case studies in manufacturing and service sector as discussed briefly.

\subsection{Literature Review on MOORA}

Manufacturing sectors are those involving numerous activities from production of a pin to assembling of part types for making up a complex structure. Manufacturing covers mass production, job shop and batch production that are a real wealth for any country in terms of employment and constitute as the back bone for service sector [37].Service sector are those that pacify the daily commercial need of the human being by catering them with high loyalty. The numerous cases for choosing the best alternative from conflicting objectives by using MOORA in manufacturing and service sectors are discussed through intensify realization

Table-1. Comparison of MOORA with MADM approaches

\begin{tabular}{|c|c|c|c|}
\hline MADM method & $\begin{array}{c}\text { Computational } \\
\text { Time }\end{array}$ & Simplicity & $\begin{array}{c}\text { Mathematical } \\
\text { calculations } \\
\text { required }\end{array}$ \\
\hline MOORA & very less & very simple & Minimum \\
\hline AHP & very high & very critical & Maximum \\
\hline ANP & Moderate & Moderately critical & Moderate \\
\hline
\end{tabular}


International Journal of Fuzzy Logic Systems (IJFLS) Vol.6, No.2, April 2016

\begin{tabular}{|c|c|c|c|}
\hline GRA & very high & very critical & Maximum \\
\hline VIKOR & Less & Simple & Moderate \\
\hline GTA & very high & very critical & Maximum \\
\hline ELECTRE & High & Moderately critical & Moderate \\
\hline DEA & very high & very critical & Maximum \\
\hline TOPSIS & Moderate & Moderately critical & Moderate \\
\hline PROMTHEE & High & Moderately critical & Moderate \\
\hline
\end{tabular}

\subsubsection{MOORA in Manufacturing Sector}

[22] Espouses the study on using AHP and MOORA for choosing the best of wire electronic discharge machining (WEDM) process. The study was conducted by using taguchi OA for identifying the best value for multi objective responses material removal rate, kerb width and surface roughness, on other side AHP a best MCDM approach had been used for conducting the weight and consistency for the three aforesaid responses along with usage of multi criteria decision making approach known as MOORA for choosing the best WEDM. The experimentation using OA choses one among best input parameters such as pulse on time, pulse off time, wire feed rate, wire tension, servo voltage and flushing pressure. Evaluation through AHP reveals the subjective weight for the three criteria as $\mathrm{w} 1=0.5469, \mathrm{w} 2=0.3445$, w $3=0.1085$ with consistency ratio $(C R<0.1)$. Similarly the usage of MOORA with Taguchi OW reveals the optimal trial as 19 out of 27 trial to give the best of material removal rate, kerb width and surface roughness in WEDM process.

[25] Portrays as study on choosing the best non-traditional machining process for the laboratory in national institute of technology-agartala. The cross functional team had been formed that comprises of individuals from NIT for chosing the best non-traditional machine. The team had used two new multi criteria or attribute decision making approach such as MOORA and multi objective optimization on the basis of simple ratio analysis(MOOSRA) for chosing the best among seven alternatives such as ultrasonic machining(USM), abrasive jet machining (AJM), electrochemical machining (ECM), EDM, WEDM, Electrical Beam Machining (EBM) and laser beam machining (LBM). The analysis, brainstorming session reveal the imperative criteria as tolerance, surface finish, power requirement, material removal rate, cost, tooling and fixture, tool consumption, safety, work material and shape feature. The team perform the analysis in two fold manner initially to calculate the weight of criteria using AHP followed by choosing the best among seven non-traditional machining process using MOORA and MOOSRA. Normalization, consistency and performance score reveal the ranking of EDM with first rank followed by ECM and EBM with USM at penultimate position concluded by ECM.

[27] Portrays that critical empowerment faced by purchasing managers was the performance evaluation and monitoring of suppliers that can provide high success for an organization. The choosing of best among four suppliers was covered in this study that makes up supplier selection a multi criteria problem that include both tangible and non-tangible factors. The four suppliers cater a chemical and bio technology concern in India. In Initial phase, data had been mined from chemical and biotechnological industries through a questionnaire and then performing evaluation through 1-5 likert scaling. The results obtained from likert scaling reveals four imperative 
criteria's in chemical and biotechnological concern namely total cost, quality service, on-time delivery and pollution causing factors. In next phase, fuzzy along with MOORA approach had been applied to choose the best among four suppliers who satisfies aforesaid criteria's by generating decision matrix. Evaluation through MOORA and fuzzy illustrate supplier 1 as best over other three of them to cater chemical and biotechnology concern. In future, fuzzy MOORA a simplified approach for engineers\managers will find a very easy way in suitable applications.

[17] Espouses on pragmatic usage of MOORA for converting MOO to SOO. The problem had been looked after effectively by taking up a case in washing machine manufacturing concern in turkey. By prolong instigation on shop floor in washing machine manufacturing concern reveals the controllable factors in washing machine as depth of washing machine body side panel (A), washing machine's body panel thickness (B), insulation type of washing machine motor $(\mathrm{C})$ and belt thickness of washing machine motor (D) that impacts dual responses namely noise level of the washing machine in $\mathrm{dB}$ with lower the better (LB) quality characteristics and spin revolution of entered resonate with higher the better $(\mathrm{HB})$ quality characteristics by varying all at two levels. The experimental study had been conducted using taguchi level-8 orthogonal array (OA) with ten replications for each treatment combination in washing machine and selection of optimal alternative was done using MOORA. Result Analysis through MOORA based taguchi design reveals input optimal condition as washing machine body panel to be new, washing machine body thickness as 0.9 , insulation type of washing machine motor as type-A and belt thickness at nominal range. The results derived through taguchi MOORA are compared with taguchi GRA, taguchi TOPSIS and taguchi VIKOR that shows out MOORA as a best optimization tool for modelling in industrial application. In the verge of future, MOORA can be used in similar applications with dependence.

[15] Investigated a study on applying MOORA for solving MOO problem in six various welding processes such as submerged arc welding, gas tungsten arc welding, gas metal arc welding, $\mathrm{CO}_{2}$ laser welding and friction stir welding. The study corroborate an insight on comparing results of GA, taguchi method(TM), GRA, support vector regression (SVR), generalized reduced gradient method (GRG) and neural network (NN) with MOORA in six various welding process. In submerged arc welding, the TM with GRA was hybridized for monitoring heat affecting zone, bed width, penetration and reinforcement using process input such as slog mix, basicity index and current. The results reveal MOORA gives alike ranking as TM with GRA. Similarly, an experimental study on monitoring front height, front width, back height and back width in gas tungsten arc welding was taken up using TM for getting best weld bead geometry. The optimal condition obtained using TM provide comparable results with MOORA. Study on monitoring ultimate tensile strength (UTS) was done using SVR in gas metal arc welding that provides a reasonable comparable ranking with MOORA. Monitoring of best optimal welding parameters in $\mathrm{CO}_{2}$ laser welding was done using GA and performing generations by NN provides the worthy comparison on ranking with MOORA. Dual studies were done in friction stir welding for monitoring UTS using GRA, whose results were better with MOORA evaluation. The comparison of other MODM approach with MOORA reveals MOORA as a highly flexible, applicable and potential approach in solving complex decision making problems. In future, MOORA method can be used for solving various selection problems in real time manufacturing environment. 
International Journal of Fuzzy Logic Systems (IJFLS) Vol.6, No.2, April 2016

[2] Illustrate that making up of decision for flexible manufacturing system (FMS) proves to be an intrication of satisfying numerous criteria's with conflicting attributes. This paper studies out usage of MOORA for performing decision making through sceptical amalgamation of various stratum in production system. The problem on choosing appropriate product design for power electronic device was taken as a case to choose best of ten alternatives by satisfying three different attributes namely manufacturing cost, junction temperature and thermal cycles. The optimal decision on choosing best of ten was done using MOORA. The evaluation through MOORA reveals design 5 and 1 as best that gets correlated with alternative selection already performed using AHP. In similar way, problem on choosing four alternative plant layouts was studied up by considering five performance attributes. The study also makes up a comparison between MOORA and weighed Euclidean distance based approach (WEDBA) that reveals layout design 2 as best and 1 as worst using both approaches. In similar way, choosing of best FMS was studied up by comparing MOORA result with AHP that reveals FMS2 as best with FMS 4 occupies least in performance ranking in both cases. The ranking of best method for performing welding process to join mild steel $(0.2 \%$ of $\mathrm{C})$ of $6 \mathrm{~mm}$ thickness was done by considering three welding process namely shield metal arc welding(SMAW), gas tungsten arc welding(GTAW) and gas metal arc welding (GMAW) with six attributes. Optimization analysis through MOORA reveals SMAW as best among three processes with GMAW occupying last position. The study on using MOORA to choose best among twenty suppliers was done by performing evaluation through DEA in agricultural and construction equipment by satisfying five criteria's. The evaluation illustrate supplier 10 as best among others. In future, MOORA a simple ratio analysis approach with less mathematical calculations have a wide scope of developing using software like $\mathrm{C}++$ language.

[18] Conducted a study on selection of material that plays a focal part in design and functioning of products. The study reveals that selection of material can be done in least complicated manner with high applicability, simplicity and accuracy using MOORA, reference point theory and full multiplicative from of MOORA (MULTIMOORA) by looking out four various case studies. In initial case, the choosing of appropriate material for designing a flywheel was done using four criteria's with ten different materials that was already analyzed through TOPSIS. Analyization reveals material 9 as imperative and 10 as menial. Results obtained through TOPSIS were compared with MOORA, MULTIMOORA and reference point approach that gives out same ranking. In second case, material selection was done for building up a cryogenic storage tank by choosing seven different materials along with seven performance criteria's for storing nitrogen. The evaluation made-up through MOORA, reference point and MULTIMOORA reveals material 3 as best and material 2 as worst ranked for building up a cryogenic tank. Third case study chooses a material for a product that was to be operated at high temperature in oxygen rich environment using six various materials and four criteria's. Analysis through MOORA was compared with MULTIMOORA and reference point approach reveals material 5 as best with material 1 in last position. The final case study uses up a simplified fuzzy logic to choose the best material for sailing boat mast. The study chooses fifteen different materials with five performance criteria's. Data analysis through fuzzy logic reveals same results as MOORA, MULTIMOORA and reference point by ranking material 15 as best suited material for sailing boat mast. In later days, MOORA, MULTIMOORA and reference point approaches can be applied with other decision making scenario with more criteria's and alternatives. 
International Journal of Fuzzy Logic Systems (IJFLS) Vol.6, No.2, April 2016

[28] Espouses that MCDM method provides an opportunity for choosing frequently acceptable alternatives based on conditions that are stated using criteria. There exist numerous MCDM methods such as compromise programming, AHP, TOPSIS, ELECTRE, PROMTHEE, COPRAS, VIKOR and additive ratio assessment (ARAS). This article explores an extension of MOORA method to be used along with triangular fuzzy numbers by integrating with ratio system and reference point system in fuzzy environment. The case was taken up in a mining company that scheduled to start up exploitation of new mine in Serbia. The problem faced by mining company was the transportation distance to new mine from existing location for performing grinding that was expensive. To avoid from these problem experts like's to consider three alternatives of grinding circuit design such as A1, A2 and A3 that should pacify five criteria's namely grinding efficiency, economic efficiency, technological reliability, capital investment costs and environmental impact. Choosing of best grinding circuit design was done in two fold manner initially by using fuzzy ratio system with MOORA by determining overall fuzzy performance index, de-fuzzyfication and selection of desirable alternatives that reveals grinding circuit design $\mathrm{A} 3$ as dominating over A1 and A2.On other side, fuzzy reference point system with MOORA was done for choosing the best design by calculating the distance between fuzzy ratings and reference point that reveals grinding circuit design A3 as dominating in Serbian mining company. In future, MOORA method can be used as a basis for research and authors depending on the problem solved by choosing relevant one.

[14] Diligently erudite that decision making process prove to be highly arduous especially in assessing the appropriateness of a project from engineering standpoint. The case covers selecting best of five profitable investment projects that can levy high growth and prosperity for an organization. Selection of projects involves complications that was overcome through newly proposed MOORA method along with standard deviation (SDV). MOORA a MCDM method was used for choosing the best alternative with conflicting criteria's whose difference in significance among objectives can be evaluated using SDV. The four important criteria's chosen for study were net present value (NPV), rate of return(ROR), payback Period(PB) and project risk $(\mathrm{PR})$ in manufacturing organization that can provide profitable investments. Evaluation made-up through MOORA and SDV identifies project 3 as best that provides highest NPV, ROR with lowest PB and PR followed by project 2 and quelled by project 5.In future, MOORA can be combined with other MCDM methods.

[11] Illustrate an accustom challenges of global competitiveness in manufacturing organization makes them to spurt over effective decision making ability for identifying and choosing the best alternative. This study acclimatise a new MODM approach namely MOORA for evaluating and choosing six decision making problems in advance manufacturing system (AMS). The initial selection was made on industrial robot by comparing six various criteria's. The comparison reveals robot 2 (cybo tech V15) as best and robot 5(PUMA 500/600) occupying the worst ranking. In same implication, the setting up of FMS was done by comparing seven different alternatives such as FMS1 to FMS7 and judging using MOORA reveals alternative FMS7 as best with alternative FMS8 occupying last position. In similar way, MOORA had been used for selecting best machine tool, non traditional machining (NTM) process, rapid prototyping (RP) process, computerized numerical control $(\mathrm{CNC})$ and automated inspection system to obtain the best AMS. In future, MOORA has a huge scope of applying with wide range of problems in real time manufacturing environment. 
International Journal of Fuzzy Logic Systems (IJFLS) Vol.6, No.2, April 2016

[16] Espouses milling operation was a pure metal cutting process done using a rotary cutter. The productivity and competitiveness of economical usage in machining operations plays a salient role by selecting best cutting parameters in process planning of metal parts. The six different decision making problems in milling process was chosen as a case by using a potential, flexible and applicable MOORA method. The first case uses MOORA evaluation in side milling process to identify the optimal process parameters such as cutting speed, feed rate, axial depth of cut, radial depth of cut for controlling material removal rate (MRR). The evaluation was already done using grey-fuzzy and graph theory matrix analysis (GTMA) that makes up a comparable ranking with MOORA method. Similarly, MOORA was used along with grey-taguchi, TM to evaluate the best process parameters for controlling average surface roughness, average tool life in end milling, side milling, end milling, face milling and milling process. The comparability study on six various decision making problems tangibly illustrate MOORA as highly stable, simple and easy to implement decision making approach with less mathematical calculations. Thus provides the applicability, potentiality and flexibility of using MOORA in milling process.

\subsubsection{MOORA in Service Sector}

[41] Studied on using the applicability of industrial engineering in the best work area using fuzzy AHP and fuzzy MOORA approach. The evaluation start up with the best work area selection for choosing industrial engineering as career for students based on criteria's such as payment, job satisfaction, career opportunity, productive, goal, status, pressure, social opportunity, employment deficit and jib easiness. The work area chosen for study were health, finance, banking, manufacturing, technology, logistics, software/informatics and academics. The choosing of best work area to work along with satisfying all the aforesaid criteria was done initially through questionnaire, followed by usage of MOORA for selecting best work area. The evaluation through fuzzy AHP and fuzzy MOORA illustrate the best three working area for students and graduates to apply industrial engineering was technology, software and finance/banking. The stability of chosen alternative were tested through sensitivity analysis by varying criteria weights to $10 \%$ that reveals the chosen ranking were alike.

[13] Concentrate on assessing the performance of Indian technical education system. In modern era, the technical education system faces an onerous task due to liberalization and globalization of Indian economy. The study had been conducted to assess the performance of seven Indian institute of technology (IIT) such as Kharagpur, Bombay, Madras, Kanpur, Delhi, Guwahati and Roorkee. Evaluation parameters to assess the performance of aforesaid IIT had been chosen as faculty strength, student intake, number of Ph.D. awarded, number of patents applied, campus area in acres and tuition fees per semester. Evaluation was done using a nuance multi criteria analysis based performance evaluation known as subjective and objective weight integrated approach (SOWIA) and MOORA, the SOWIA approach had been used for calculating integrated, objective and subjective weights of each criteria for assessing the IIT with MOORA used for ranking the optimal OOT with effective criterion ranking. Usage of SOWIA and MOORA reveals IIT- Kharagpur as best among other six IIT in India. The robustness of obtained output had been assessed using sensitivity analysis and comparison was made with AHP-COPRAS using non parametric spearman test of relationship (rs) and Kendall's Tau Test (Z) reveals the result as alike obtained from SOWIA-MOORA approach. 
International Journal of Fuzzy Logic Systems (IJFLS) Vol.6, No.2, April 2016

[21] Espouses a study in special education and rehabilitation centre that were introduced for individuals to create a cosy living environment for nurturing their skills by achieving self reliance. The case was taken up by tapping three different special education and rehabilitation centre namely nida, parilti and ilgim in turkey. The best of choosing mentioned three rehabilitation centres was done by satisfying six various criteria's such as education, ergonomics, compliance of corporation building, cost, publication with prestige and assessment of personal prestige. Initially, the weights of criteria were evaluated using triangular fuzzy numbers with AHP followed by choosing a best rehabilitation centre out of three was evaluated using MOORA and MULTIMOORA. Calculation results through MOORA and MULTIMOORA reveals nida as best special education and rehabilitation centre followed by ilgim and parilti. In future, same case can be analysed using grey numbers with subsequent comparison over other MCDM method.

[38] Erudite, alternative design solutions for building can be successful by applying MCDM methods with number of quantitative and qualitative criteria's. The main objective of current research work was to test the reliability of previously proposed methods such as weighed aggregated sum product assessment (WASPAS), orthogonal experimental design (OED), ARAS and multi objective particle swarm optimization algorithm (MOPSO).The case covers the selection of best design for facades in public or commercial buildings. The four building facades were chosen namely cellular concrete masonry covered by Rockwell plates and decorative plaster surface, sandwich facade panels, gas silicate masonry with Rockwell, minerit façade plates and aluminium gazing facades. Evaluation was done initially through WASPAS by varying $\lambda$ value from 0 to 1 for monitoring the robustness of chosen optimal facade in building design that reveals sandwich facade panels as best in the range of varying $\lambda$ from 0 to 0.4 and aluminium gazing facade being good with varying $\lambda$ from 0.5 to 1 .Comparable manipulation through MOORA's ratio, reference point and MULTIMOORA approach reveals "sandwich" panel as best for public façade.

[39] Conducted a study on effective selection of element for renovating building to enhance energy effectiveness and air humidity using extension of MOORA and MULTIMOORA with interval data. In Lithuania, the panel buildings were perturbed before 40 years that were highly dilipated with poor thermal insulation performance, microclimate and relative humidity. The panel building in Lithuania chosen for analysis was a five storey building whose building structures like roof, window, doors, cellars, thermal bridges etc. were assessed through extension of MOORA and MULTIMOORA with interval data. Initially the walls of building had been chosen for assessing energy effectiveness that depends on thermal resistance, structure refurbishment price, energy savings and payback time. The evaluation for the best of five wall in five storey building results in ranking alternative four as best in five storey building with maximum thermal resistance and menial one being alternative three. In similar way thermal resistance was calculated for walls, roof, cellular ceilings and windows in five storey building.

[31] Espouses decision making was the searching of optimal alternatives from available feasible solutions. In real time, findings of optimal alternative effects the versatile conflicting criteria's for judging the decisions which are commonly known as MCDM approach. This paper explores an extension of MOORA, reference point and ratio analysis approach by integrating with interval grey number. Initially, MOORA had been used along with interval grey numbers followed by simultaneous usage of crisp and interval grey numbers and finally with interval grey numbers and whitening coefficient. MOORA also had been compared with simple additive weightage (SAW), TOPSIS, VIKOR and COPRAS. In first case, the optimal alternatives were evaluated using 
COPRAS compared with MOORA and interval grey numbers that show up both the rankings are alike. The second case takes up a comparison of MOORA with crisp and interval grey numbers along with SAW Grey analysis (SAW-G) by performing normalization, optimization that reveals par in ranking. In third case, MOORA was applied with interval grey numbers to eliminate the uncertainty by comparing with COPRAS Grey analysis (COPRAS-G) that gives out comparable ranking in decision makers pessimistic, optimistic and moderate mind set. The conclusion made up overall is, usage of MOORA with extensive measures provide simple and effective solution for real world problems.

[5] Portrays, a country is a group of regions that contributes towards GDP by producing a value added products. The Vilnius gediminas technical university takes up a study on mapping out multiple criteria's for sustainable development in cities and countries of Lithuania .The study on regional sustainable development in Lithuania cities were done by selecting ten Lithuania cities such as vilinus,klaipeda,Kaunas,telsiai,utena,alytus,panevezys,siauliai,marijampole and taurage. Regional development through GDP contribution on each region's was identified by selecting sixteen various attributes that rove to be focal. Study uses MOORA over other MADM and MODM approaches, since MOORA was a well-being, cardinal approach that puts up customer sovereignty as an emphasize goal. MOORA chooses best of Ten Lithuania Cities through effective contribution for well-being economy that can provide good material wealth, health, education, all kind of security and concerning the environment. The evaluation through normalization, optimization and importance leaves Vilnius, Klaipeda and Kaunas as good wellbeing districts with telsiai, taurage and Siauliai occupies poorer position. The paper also shows out an effective project that can be tapped in industrialization and construction, commerce and tourism, labour drain to improve the GDP in Lithuanian country. In future, commercialization and industrialization on Lithuanian cities with decline labour drain over abroad would isolate vulnerability in well-being of inhabitants.

[19] Illustrate that pragmatic usage of building design was to acclimatize towards ameliorated and embody living environment conditions with a cosy surrounding by controlling energy losses in building. Heat energy losses in building can be controlled to a large extent by properly selecting external wall and window. This study investigate the selection of six various wall and window for building design such as A1, A2, A3, A4, A5 and A6 on four directions by satisfying seven various criteria such as heat loss through building wall, building windows, bearer thermal bridges, above rated air infiltration, external heat inflows in the building, total heat consumption with external walls and window price ratio. The criteria's representing heat losses were non-beneficial with heat flow and price ratio being beneficial. Mathematical manipulation through MOORA, MULTIMOORA and reference point theory reveals A2 reduces heat energy losses in building followed by A6 or A3 with A1, A4 and A5 was isolated by decision makers. The MOORA and MULTIMOORA theoretical model proven to be effective in real life situation can be successfully applied in solving utility problem in other sectors. 
International Journal of Fuzzy Logic Systems (IJFLS) Vol.6, No.2, April 2016

[4] Portrays in a broader sense that transition economies are making up of transition from plan to market. In 1990, countries of Soviet Union and central with Eastern Europe eradicate central planning, liberalized taxation, banking, customers and independent central banking. This study espouse on project management that are commonly used in a market economy. Project management predicts project for analyization that will make up a new economic activity by renovating existing economic activity. Project management involves combination of both micro and macro-economic objectives by selecting a case with multiple objectives in Wuhan, Hubei provenance, china. The empirical problem with Wuhan was to set up an inland seaport, since Wuhan was proximally located $1000 \mathrm{~km}$ inland. Choosing a best of three projects for setting up an inland port in Wuhan was a MOO problem that was verified using MOORA ratio system, reference point system, multiplicative form and MULTIMOORA. The chosen micro and macroeconomic criteria's for project selection in this case were such as NPV, internal rate of return (IRR),PB, government income, Employment, value added (VA), risk, balance payment and investment. Technical evaluation through MOORA, multiplicative form and MULTIMOORA reveals project $\mathrm{A}$ as good for earning government income with project $\mathrm{C}$ increasing employment and project $\mathrm{B}$ occupies penultimate position.

[6] Reveal definition of robustness in econometrics was an error term in a linear equation that was broadened from a cardinal to qualitative one. The error term in linear equation was initiated by origin for robustness in econometrics. On other side, robustness was connected with residual terms, slack, dummy variables and outliers. The significance of robustness were explained in three fold ways first by considering robustness in cardinal scales, second by indicating the robustness as either vogue or arbitrary and finally by completeness in statistical universe with events and opinions. These interpretations are experimented by taking up a case in facility sector in Lithuania. Facility sectors are those performing servicing operations like acquisition, leasing, renting, managing, supervision, maintenance and repairing of existing buildings in private dwellings of Vilnius, capital of Lithuania. The study was done by selecting 15 largest maintenance contractors for performing facility operation in private dwellings of Vilnius by having intensified discussion with a panel of 30 random dwelling owners in Vilnius. The panel suggests twenty criteria's for maintaining and choosing contractors in which eleven were expressed with rejection by choosing other nine criteria for study. Evaluation through MOORA and reference point approach ranks contractor 6 as first for size and experience with second for effectiveness followed by contractor 10 in second position for effectiveness and size succeeded by contractor 1 and contractor 4.A newer research based on newer data, larger samples and large number of quantifiable objective will increase the robustness of outcome.

[8] Illustrate that construction projects were reliable venture with peculiar features such as long period, tedious process and changing environment.The study narrowly focus on choosing best contractor, who plays a focal part in customer sovereignty of construction in building's. The choosing of best contractor was a multi criteria problem that should satisfy eligible criteria in dwellings of Vilnius, capital of Lithuania. This study chooses up the best contractor by using a new MODM approach namely MOORA in two fold manner initially through ratio and then using reference point analysis by making up a decision matrix for selecting best among fifteen contractors who satisfy aforementioned eligible criteria's. Manipulation through MOORA ratio analysis and reference point theory reveals contractor six as first for size, experience and second on effectiveness followed by contractor ten ranked first for effectiveness and second for size. 
International Journal of Fuzzy Logic Systems (IJFLS) Vol.6, No.2, April 2016

Ranking on contractors reveals that neither of chosen contractors was cost effective. In later days, a newer research can be done with newer data, large samples and large number of quantified objectives using MOORA.

[7] Erudite that decision making proves to be an imperative part of human brain were values, belief and perceptions urge it to be successful. The case study maps out choosing of best road design in expanding a highway of Thuringia, Germany from 4 to 6 lanes using a MODM approach namely MOORA. The MOORA a MODM technique was used for making up the comparison between six various types of road design such as concrete surfacing with changing axis and gradient, asphalt concrete surfacing by changing axis and retaining gradient, concrete surfacing with changing axis and retaining gradient, asphalt concrete surfacing by changing axis and gradient, concrete surfacing with retaining axis and gradient and asphalt concrete surface with axis and retaining radiant. The five performance criteria's chosen for road selection were such as longevity, cost price, environment protection, economic validity and construction duration. Numerical manipulation, optimization and imperativeness through MOORA identifies the auspicious condition for laying road can be done by changing the axis and retaining the gradient of highway with concrete surfacing in Thuringia, Germany. The proposed model leaves a path to apply the MOORA a sceptical ratio analysis approach for solving similar utility problems in construction sector.

[20] Espouse that demand for purchasing newly build houses or apartments are growing high day in day out. During purchasing of houses, customers do pay high attention towards price, maintenance cost, living space, location Etc., by ignoring inner climate in houses. A cosy inner climate will eradicate propagating of bacteria's within the room along with controlling of vapour condensing and moulding. This article takes up a study to analyse the inner climate in five storied house in naujoji, Vilnia. The assessment of inner climate in ten living rooms of a five storied house was done by looking out six important criteria's such as air turnover ratio, air humidity, air temperature, illumination intensity, air flow rate and dew point. The data on each afore said criteria's for ten living rooms were obtained using metrel equipment MJ6201EU with calibrated certificate. Calculations were performed using MOORA, initially by making up decision matrix followed by normalizing, determining complex rationality and ranking that leaves out living room 7 as best with good air turnover ratio, air humidity, air temperature, illumination intensity with less air flow rate and dew point in five storied building. In future, the data obtained using MOORA method may be used in determining the market value of flats or apartments.

[10] Identifies a transition economy as previous accumulated economies of central and eastern Europe or Asia that were transpired into controlled market economies. This paper narrowly tailors on privatization in transition economy were the government or state enterprises are turned over into private owners. The salient goal of the study was to optimize privatization process in transition economy to increase the effectiveness of internal return rate (IRR), productivity and declining of payback period from management side. On other side, a study contribute on increasing macro economical attributes namely maximum of investments, employment and influence of current balance payment for assessing the privatization in transition economy. The article initially covers the comparison of MOORA with other reference point approaches like rank correlation, minkowski metric (1986), tchebycheff metric (1821-1894), Euclidean distance metric with additive weightage, TOPSIS. The comparison reveals MOORA gives priority to the 
mid way solutions by ranking it first within the convex zone over other approaches. The mentioned context urges to use MOORA with well being economy of transition in Lithuania, which gives customer sovereignty as highest preference attributes over productivity. The study was conducted by selecting three various projects such as project $A, B$ and $C$ to reveal the difference in ranking between MOORA and reference point approach that selects project $\mathrm{A}$ and $\mathrm{B}$ as first. The conclusion was made-up with contradicted results from two approaches by having Project $\mathrm{A}$ and $\mathrm{C}$ first rank for four objectives with no first rank for project $\mathrm{B}$. The herewith comparison on three projects culminate that project $\mathrm{A}$ and $\mathrm{C}$ would dominate $\mathrm{B}$ at four dominating positions to give preference for obtaining better mid way solutions as per economic law of decreasing marginal utility. In later days, a newer research can be done with newer data, large samples and large number of quantified objectives.

\subsubsection{MOORA Extension:}

In current era, the usage of crisp numbers in classical MCDM method were extended for usage with interval grey number [40].The review was done to identify the extension of MOORA with other MCDM approaches. The survey leads to extending MOORA with interval grey numbers, MOORA with simultaneous use of crisp and interval grey number and MOORA with interval grey number and whitening coefficient. The table 4 will list out the MOORA extension in organization work area.

Table -2 MOORA Extension and Comparison

\begin{tabular}{|c|c|c|c|c|}
\hline \multirow[b]{2}{*}{$\begin{array}{c}\text { S } \\
\text { No }\end{array}$} & \multirow[b]{2}{*}{ Author } & \multicolumn{2}{|c|}{ MOORA } & \multirow[b]{2}{*}{ Benefits } \\
\hline & & Extension & Comparison & \\
\hline 1 & $\begin{array}{l}\text { Zavadaskas } \\
\text { et al.,(2008) }\end{array}$ & $\begin{array}{l}\text { MOORA with } \\
\text { interval grey } \\
\text { number }\end{array}$ & $\begin{array}{l}\text { COPRAS with } \\
\text { interval grey } \\
\text { number }\end{array}$ & $\begin{array}{c}\text { Concomitant on MOORA - } \\
\text { G and COPRAS-G were } \\
\text { alike }\end{array}$ \\
\hline 2 & $\begin{array}{l}\text { Medinickiene } \\
\text { et al.,(2010) }\end{array}$ & $\begin{array}{lr}\text { MOORA } & \text { with } \\
\text { crisp } & \text { and } \\
\text { interval } & \text { grey } \\
\text { number } & \end{array}$ & $\begin{array}{l}\text { SAW with grey } \\
\text { number }\end{array}$ & $\begin{array}{l}\text { Concomitant on MOORA - } \\
\mathrm{G} \text { and SAW-G were not } \\
\text { alike }\end{array}$ \\
\hline 3 & $\begin{array}{l}\text { Zavadaskas } \\
\text { et al.,(2009a) }\end{array}$ & $\begin{array}{ll}\text { MOORA } & \text { with } \\
\text { interval } & \text { grey } \\
\text { number } & \end{array}$ & $\begin{array}{ll}\text { COPRAS } & \text { with } \\
\text { interval } & \text { grey } \\
\text { number } & \end{array}$ & $\begin{array}{l}\text { Concomitant on MOORA - } \\
\mathrm{G} \text { and COPRAS-G were } \\
\text { alike }\end{array}$ \\
\hline
\end{tabular}

The table 2 reveal the ranking(optimistic, moderate and pessimistic) concomitant that were alike for choosing alternative in all the three cases with MOORA and COPRAS extension but not alike with other extension in organization work area. 


\section{GAP ASSESSMENT}

The study conducted by various scholars in manufacturing and service sector illustrate, organization faces accustom challenges due to ineffective decision making that deteriorates priority and worthiness of decision makers. To overcome such a situation, organizations needs an aid of effective decision making tool that involves creative development and identification of options, clarity in judgement, firmness of decision and effective implementation that all can be done using MOORA. MOORA a pure cardinal approach was used effectively for solving realtime complex decision making problem in eleven cases of manufacturing and twelve cases of service sector as shown in Table 3 and Table 4.MOORA with such an empirical benefit have a wide scope of applicability in other manufacturing and service sector such as product and process design, network analysis, aircraft design, automobile design, thermal power plant, nuclear power plant, chemical industry, cement industry, hospitals, banks, schools, finance Etc. The usage of MOORA will allow decision makers to choose the best alternative within less computational time, high stability and reduce cost.

\section{CONCLUSIONS}

In this article, analysis on MOORA a MADM approach was done through various case studies in manufacturing and service sector that corroborate a usage of MOORA in two fold manner

1. MOORA was compared with other endemically used MADM approaches that reveal, MOORA chooses best alternative with high simpleness, less computational time and basic mathematical calculations along with no usage of extra parameters like $v$ in VIKOR and $\xi$ in GRA method.

2. In the second phase, intensified realization through sparse cases available in using MOORA was studied out to illustrate the imperative benefits and scope of applicability for solving real time empirical problems.

3. In future span, providing extension for MOORA,MOOSRA and MULTIMOORA (Multiplicative form of MOORA) using interval grey numbers and fuzzy have an wide scope in manufacturing and service sectors to eradicate vagueness, imprecision in decision maker subjectivity for choosing the best alternative with conflicting criteria.

\section{REFERENCES}

[1] Asekun \& Fourie, (2015) "Selection of a decision model for rolling stock maintenance scheduling", South African Journal of Industrial Engineering,Vol.26,No.1,pp 135-149.

[2] Attri \& Grover,(2013) "Decision making over the production system life cycle:MOORA method", International journal System Assurance Engineering Management, Vol.5,No.3,pp 320-328.

[3] Bandyopadhyay \& Saha,(2013) "Unsupervised Classification", Springer-verlag Berlin Heidelberg New York Dordreeht London.

[4] Brauers \& Zavadskas, (2010) "Project management by multimoora as an instrument for transition economies", Technological and Economical Development of. Econonomy, Vol. 16,No.1,pp 5-24.

[5] Brauers, Ginevicius \& Podvezko, (2010) "Regional development in Lithuania considering multiple objectives by the MOORA method", Technological and Economical Development of. Econonomy, Vol.16,No.4,pp 613-640. 
International Journal of Fuzzy Logic Systems (IJFLS) Vol.6, No.2, April 2016

[6] Brauers \& Zavadskas, (2009) "Robustness of the multi-objective MOORA method with a test for the facilities sector", Technological and Economic Development of. Econonomy, Vol.15, No.2, pp 352375.

[7] Brauers, Zavadaskas, Peldschus \& Turskis, (2008) "Multi-objective optimization of road design alternatives with an application of the MOORA method", The $25^{\text {th }}$ International Symposium on Automation and Robotics in Construction, pp 541-548.

[8] Brauers, Zavadskas, Turskis \& Vilutiene, (2008) "Multi-objective contractor's ranking by applying the MOORA method", Journal of Business Economics and Management Vol.9, No.4, pp 245-255.

[9] Bernroider \& Stix, (2007) "A method using weight restrections in data envelopment analysis for ranking and validity issues in decision making", Procedia Engineering, Vol. 34, pp 2637-2647.

[10] Brauers \& Zavadskas, (2006) "The MOORA method and its application to privatization in a transition economy", Control and Cybernetics, Vol. 35, No.2, pp 445-469.

[11] Chakraborty,(2011) "Applications of the MOORA method for decision making in manufacturing environment", International Journal of Advanced Manufacturing Technolog, Vol.54, No.9-12, pp $1155-1166$.

[12] Chen, Chang \& Huang, (2009) "Applying six-sigma methodology in the Kano quality model: An example of the stationery industry", Total Quality Management and Business Excellence, Vol.20, No.2, pp 153-170.

[13] Das, Sarkar and Ray, (2015) "On the performance of indian technical institutions: a combined SOWIA-MOORA approach", OPSEARCH.

[14] El-Santawy \& Ahmed, (2012) "Analysis of project selection by using SDV-MOORA Approach", Life science Journal, Vol.9, No.2, pp 129-131.

[15] Gadakh, Shinde \& Khemnar, (2013) "Optimization of welding process parameters using MOORA method", International Journal of Advanced Manufacturing Technology, Vol.69,No.9-12,pp 20312039.

[16] Gadakh, (2011) "Application of MOORA method for parametric optimization of milling process", International Journal of Applied Engineering Research, Vol.1, No.4, pp 743-758.

[17] İç \& Yıldırım,(2013) "MOORA-based Taguchi optimisation for improving product or process quality", International journal of Production Reserach, Vol.51, No.11, pp 3321-3341.

[18] Karande \& Chakraborty, (2012) "Application of multi-objective optimization on the basis of ratio analysis (MOORA) method for materials selection", Material and Design, Vol. 37, pp 317-324.

[19] Kracka, Brauers \& Zavadaskas, (2010) "Ranking Heating Losses in a Building by Applying the MULTIMOORA", Engineering Economic, Vol.21, No.4, pp 352-359.

[20] Kalibatas \& Turskis, (2008) "Multicriteria evaluation of inner climate by using MOORA method", Information Technology and Control, Vol.37, No. 1, pp 79-83.

[21] Özçelik, Ayodgan \& Gencer, (2014) "A Hybrid Moora-Fuzzy Algorithm For Special Education and Rehabilitation Center Selection", Journal of Miltary and Information Science, Vol.2, No.3, pp 53-61.

[22] Patel and Maniya (2015) "Application of AHP/MOORA method to select wire cute electrical discharge machining process parameter to cut EN31 alloys steel with brasswire", Material Today: Proceedings, $\quad$ Vol $2, \quad$ pp $2496-2503$.

[23] Pieterse, Grobbelaar \& Visser, (2014) "Evaluating the Ability of Decision Makers to Estimate Risks Effectively in Industrial Applications", South African Journal of Industrial Engineering, Vol.25, No.3, pp 9-24.

[24] Roghanian \& Alipour, (2014) "A fuzzy model for achieving lean attributes for competitive advantages development using AHP-QFD-PROMTHEE", Journal of Industrial Engineering International, Vol.68, No.10, pp 1-11.

[25] Sarkar, Panja, Das and Sarkar (2015) "Developing an efficient decision support system for nontraditional machine selection: an application of MOORA and MOOSRA", Production and $\begin{array}{lllll}\text { Manufacturing } & \text { Research, } & \text { Vol.3, } & \text { No.1, } & \text { 324-342. }\end{array}$ 
[26] Shumon \& Ahmed, (2015) "Multi criteria model for selection of collection system in reverse logistics: A case for end of life lelectronic products", International Journal of Industrial Engineering:Theory,Applications and Practise, Vol.22, No.2.

[27] Seema Kaur \& Kumar, (2014) "Designing a mathematical model using fuzzy based MOORA method for supplier selection", International Journal of Advanced Engineering Technology, pp 16-24.

[28] Stanujkic, (2013) "An extension of the MOORA method for solving fuzzy decision making problems", Technological and Economic Development of Econonomy, Vol.19, No.1, pp S228-S255.

[29] Shieh, Chen \& Wu, (2013) "A case study of applying fuzzy dematel method to evaluate performance criteria of employment service outreach program", International Journal of Industrial Engineering:Theory,Applications and Practise, Vol.20, No.9-10.

[30] Samvedi, Jain \& Chan, (2013) "An integrated approach for machine tool selection using fuzzy analyticl hierarchy process and grey relational analysis", International Journal of Production Research, Vol.50, No.12, pp 3211-3221.

[31] Stanujkic, Magdalinovic, Jovanovic and Stojanovic, (2012) "An objective multi-criteria approach to optimization using MOORA method and interval grey numbers", Technological and Economic Development of Econonomy, Vol.18, No.2, pp 331-363.

[32] Vinodh, Prasanna \& Prakash,(2014) "Integrated Fuzzy AHP-TOPSIS for selecting the best plastic recycling method: A case study", Applied Mathematical Modelling, Vol.38, No.19-20, pp 4662-4672.

[33] Vinodh, Gautham, Ramiya \& Rajanayagam, (2010) "Application of fuzzy analytic network process for agile concept selection in a manufacturing organisation", International journal of Production Reserach., Vol.48, No.24, pp 7243-7264.

[34] Vinodh, Shivraman \& Viswesh, (2012) "AHP-based lean concept selection in a manufacturing organization", Journal of Manufacturing Technology Management, Vol.23, No.1, pp 124-136.

[35] Vinodh \& Balaji, (2011) "Fuzzy logic based leanness assessment and its decision support system", International Journal of Production Research, Vol. 49, No.13, pp 4027-4041.

[36] Vinodh, Devadasan \& Reddy, (2010) "Agility index measurement using multi grade fuzzy approach integrated in an 20 criteria agile model", International Journal of Production Research, Vol.48, No.23, pp 7159-7176.

[37] Viswanadham \& Narahari, (2009) "Performance modelling of automated manufacturing systems", Prentice Hall, Englewood Cliffs, New Jersey 07632.

[38] Zavadskas, Antucheviciene, Saparauskas \& Turskis, (2013) "Multi-criteria assessment of facades alternatives: Peculiarities of ranking methodology", Procedia Engineering, Vol.57, pp 107-112.

[39] Kracka \& Zavadaskas, (2013) "Panel building refurbishment elements effective selection by applying multiple criteria methods", International Journal of Strategic Property Management, Vol.17,No.2,pp 210-219.

[40] Stanujkic, Magdalinovic, Jovanovic and Stojanovic, (2011) “An Objective Multi-Criteria Approach to Optimization Using MOORA Method and Interval Grey Numbers", Technological and Economic Development of Economy, Vol.18, No.2, pp 331-363.

[41] Akkaya, Turanoglu and Oztas, (2016) "An Integrated Fuzzy AHP and Fuzzy MOORA Approach to the Problem of Industrial Engineering Sector Choosing", Expert System with Applications,2015.

[42] Sahu, Datta and Mahapatra, (2014) "Supply Chain Performance Benchmarking using Grey-MOORA Approach", Grey System Theory and Application, Vol.4, No.1, pp.24-55.

[43] Zavadaskas, Turskis and Kildiene, (2014) "State of Art Surveys of Overviews on MCDM/MADM methods", Technological and Economic Development of Economy, Vol.20, No.1, pp 165-179 
International Journal of Fuzzy Logic Systems (IJFLS) Vol.6, No.2, April 2016

Table-2. MOORA applications in manufacturing sector.

\begin{tabular}{|c|c|c|l|}
\hline S No & Authors & $\begin{array}{c}\text { Field Of } \\
\text { Implications }\end{array}$ & \multicolumn{1}{|c|}{ Empirical benefits } \\
\hline 1 & Patel et al. 2015 & $\begin{array}{c}\text { Machining } \\
\text { Process }\end{array}$ & $\begin{array}{l}\text { A new multi objective method for chosing optimal } \\
\text { value of output parameter. }\end{array}$ \\
\hline 2 & Sarkar et al. 2015 & $\begin{array}{c}\text { Non-traditional } \\
\text { Machining }\end{array}$ & $\begin{array}{l}\text { MOORA one of the simplest multi criteria method in } \\
\text { selecting the corresponding decision attribute. }\end{array}$ \\
\hline 3 & Seema et al. 2014 & $\begin{array}{c}\text { Supplier } \\
\text { selection }\end{array}$ & $\begin{array}{l}\text { MOORA a multi objective optimization approach } \\
\text { performs simultaneous optimization on two or more } \\
\text { conflicting attributes. }\end{array}$ \\
\hline
\end{tabular}

\begin{tabular}{|c|c|c|c|}
\hline 4 & $\begin{array}{l}\text { Yusuf Tansia Ic and } \\
\text { Sebla Yildirim } 2013\end{array}$ & $\begin{array}{l}\text { Washing } \\
\text { machine } \\
\text { manufacturing }\end{array}$ & $\begin{array}{l}\text { MOORA based taguchi method reduces } \\
\text { computational time with no extra co efficient to look } \\
\text { out as a best optimization modelling tool. }\end{array}$ \\
\hline 5 & $\begin{array}{l}\text { V.S. Gadakh et al. } \\
2013\end{array}$ & Welding process & $\begin{array}{l}\text { MOORA is highly flexible, potential and applicable } \\
\text { in solving tedious decision making problems over } \\
\text { other MODM techniques like SVR, NN, GA, TM, } \\
\text { GRA, GRG, Etc. }\end{array}$ \\
\hline 6 & $\begin{array}{l}\text { R. Attri and S. } \\
\text { Grover } 2013\end{array}$ & $\begin{array}{l}\text { Production } \\
\text { system }\end{array}$ & $\begin{array}{l}\text { MOORA chooses an optimal alternative within less } \\
\text { computational time and simple mathematical } \\
\text { calculations compared over DEA, AHP, WEDBA, } \\
\text { ANP, VIKOR, GTA, ELECTRE, TOPSIS and } \\
\text { PROMTHEE. }\end{array}$ \\
\hline 7 & $\begin{array}{l}\text { P. Karande and S. } \\
\text { Chakarborty } 2013\end{array}$ & $\begin{array}{l}\text { Material } \\
\text { Selection in } \\
\text { manufacturing } \\
\text { system }\end{array}$ & $\begin{array}{l}\text { MOORA, MULTIMOORA and reference point } \\
\text { approaches were simple, logical and systematic over } \\
\text { other MODM approaches like AHP, TOPSIS, } \\
\text { VIKOR ELECTRE, modified digital logic and } \\
\text { weighed property. }\end{array}$ \\
\hline 8 & D. Stanujkic 2013 & $\begin{array}{l}\text { Grinding circuit } \\
\text { design }\end{array}$ & $\begin{array}{l}\text { Compare with other MCDM method, MOORA was } \\
\text { highly specific in decision making. }\end{array}$ \\
\hline
\end{tabular}

\begin{tabular}{|c|c|c|l|}
\hline 9 & $\begin{array}{c}\text { M.F.El. Santawy and } \\
\text { A.N. Ahmed 2012 }\end{array}$ & Project selection & $\begin{array}{l}\text { MOORA had been used to solve complex and } \\
\text { conflicting decision making problems. }\end{array}$ \\
\hline 10 & $\begin{array}{c}\text { S. Chalraborthy } \\
2011\end{array}$ & $\begin{array}{c}\text { Advance } \\
\text { manufacturing } \\
\text { system }\end{array}$ & $\begin{array}{l}\text { MOORA improves versatile skills such as creative } \\
\text { development and identification of options, clarity in } \\
\text { judgment, firmness of decision and effective } \\
\text { implementation for making good decision making. }\end{array}$ \\
\hline 11 & V.S. Gadakh 2011 & Milling Process & $\begin{array}{l}\text { MOORA satisfies seven various conditions and was } \\
\text { highly robust in diverse manufacturing environment }\end{array}$ \\
\hline
\end{tabular}


International Journal of Fuzzy Logic Systems (IJFLS) Vol.6, No.2, April 2016

Table-3. MOORA applications in service sector.

\begin{tabular}{|c|c|c|c|}
\hline $\begin{array}{c}\text { S } \\
\text { No }\end{array}$ & Authors & $\begin{array}{c}\text { Field Of } \\
\text { Implications }\end{array}$ & Empirical benefits \\
\hline 1 & Akkaya et al. 2015 & $\begin{array}{l}\text { Industrial work area } \\
\text { selection }\end{array}$ & $\begin{array}{l}\text { MOORA makes correct choice in } \\
\text { unproblematic ultimate product }\end{array}$ \\
\hline 2 & Das et al. 2015 & $\begin{array}{l}\text { Indian Technical } \\
\text { Institution }\end{array}$ & $\begin{array}{l}\text { MOORA have several advantage such } \\
\text { as less computational time, simple and } \\
\text { stable etc. }\end{array}$ \\
\hline 4 & $\begin{array}{c}\text { Kracka and Zavadaskas } \\
2013\end{array}$ & $\begin{array}{l}\text { Panel building } \\
\text { refurbishment }\end{array}$ & $\begin{array}{l}\text { MOORA was effective in solving many real } \\
\text { life problem and extended towards other utility } \\
\text { areas. }\end{array}$ \\
\hline 5 & $\begin{array}{l}\text { E.K. Zavadaskas et al. } \\
2013\end{array}$ & Building design & $\begin{array}{l}\text { MOORA chooses best facades in public or } \\
\text { commercial buildings with skeptical } \\
\text { calculations. }\end{array}$ \\
\hline 6 & D. Stanujkic et al. 2012 & $\begin{array}{l}\text { sustainable development } \\
\text { in cities and countries of } \\
\text { Lithuanian }\end{array}$ & $\begin{array}{l}\text { Solving of multiple objectives expressed in } \\
\text { different units was equalized through different } \\
\text { objective weights that creates dilemma. To } \\
\text { avoid these MOORA uses ratio system } \\
\text { producing dimensionless numbers that involve } \\
\text { all stakeholders. }\end{array}$ \\
\hline 7 & $\begin{array}{l}\text { W.K. Brauers et al. } \\
2010\end{array}$ & $\begin{array}{l}\text { Regional development } \\
\text { In Lithuania }\end{array}$ & $\begin{array}{l}\text { MOORA satisfies all seven conditions over } \\
\text { other methods. }\end{array}$ \\
\hline 8 & M. Kracka et al. 2010 & $\begin{array}{l}\text { Heat Energy loss in } \\
\text { Designing walls and } \\
\text { windows }\end{array}$ & $\begin{array}{l}\text { The MOORA bring cardinal utilities implying } \\
\text { a final order preference for decision making. }\end{array}$ \\
\hline
\end{tabular}

\begin{tabular}{|c|c|c|c|}
\hline 9 & $\begin{array}{l}\text { W.K. M. Brauers and } \\
\text { E.K. Zavadaskas } 2010\end{array}$ & Facility sector & $\begin{array}{l}\text { MOORA satisfies all six conditions like } \\
\text { stakeholders, objectives and alternatives, non- } \\
\text { subjective, cardinal, last data and available } \\
\text { methods. }\end{array}$ \\
\hline 10 & $\begin{array}{l}\text { W.K. Brauers and E.K. } \\
\text { Zavadaskas } 2009\end{array}$ & $\begin{array}{l}\text { Project management in } \\
\text { transition economies }\end{array}$ & $\begin{array}{l}\text { MOORA satisfies all seven conditions } \\
\text { eventually by assisting with ameliorated } \\
\text { nominal group and Delphi technique. }\end{array}$ \\
\hline 11 & $\begin{array}{l}\text { W.K. Brauers et al. } \\
2008\end{array}$ & Road Design & $\begin{array}{l}\text { MOORA works on with matrix of responses in } \\
\text { alternatives on objectives where ratio are } \\
\text { applied with large scenario's and objectives }\end{array}$ \\
\hline 12 & $\begin{array}{l}\text { W.K. Brauers et al. } \\
2008\end{array}$ & Contractors Selection & $\begin{array}{l}\text { MOORA a cardinal approach involves all } \\
\text { stakeholders by which everybody was } \\
\text { interested in certain issues of service } \\
\text { organization }\end{array}$ \\
\hline 13 & $\begin{array}{l}\text { D. Kalibatas and } Z \text {. } \\
\text { Turskis } 2008\end{array}$ & Inner climate & $\begin{array}{l}\text { MOORA chooses best alternative from } \\
\text { available options. }\end{array}$ \\
\hline 14 & $\begin{array}{l}\text { W.K. Brauers and E.K. } \\
\text { Zavadaskas } 2006\end{array}$ & $\begin{array}{l}\text { Privatization in } \\
\text { transition economy }\end{array}$ & $\begin{array}{l}\text { MOORA a cardinal approach gives priority to } \\
\text { midway solution by ranking it first within } \\
\text { convex zone }\end{array}$ \\
\hline
\end{tabular}




\section{Authors}

N.Karuppanna Prasad did his M.E from Anna University of Tiruchirapalli and B.E from Anna university of Chennai. He is presently working as a senior engineer in technical training department of TVS Training and Services. He Works as an industrial engineer for 4.5 years in the field of Industrial Engineering. His research areas were optimization, quality control, and supply chain management.

Dr. K.Sekar is an Assistant Professor of Mechanical Engineering Department in National Institute of Technology (NIT) - Calicut, Kerala, India. He had done his $\mathrm{PhD}$ at Mechanical Engineering Department in NIT, Calicut, M.E in Manufacturing Engineering Department at Government College of Technology (GCT), Coimbatore and B.Tech from Production Engineering Department at Madras Institute of Technology (MIT), Anna University-Chennai. He had 2 years of industrial experience and 13 years of teaching experience. His research areas were Manufacturing, Materials, Optimization, Metal Casting, welding and Industrial Automation.

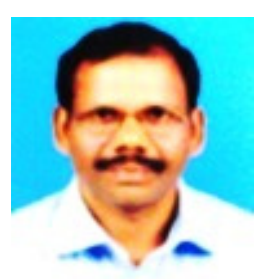

